\title{
Editorial: \\ Journal of Public Pedagogies
}

Karen Charman

Victoria University 
Welcome to the 2020 Journal of Public Pedagogies. This feels like a year that many people are wishing away. Here in Australia, and of course all over the world, we are confronted with a new relationship to place through the advent of Covid-19. Before this occurred the eastern part of Australia was engulfed by unprecedented bushfires. Now as I write, fires are occurring in North America. The idea of place and how we negotiate ourselves within this, looms large. To state the obvious, this is also entailing a new understanding of what the public is, as in some places we cannot have experiences beyond our immediate localities and then this might be a walk with one other person. However, this does not mean that we have stopped thinking about the public and in some ways grieving for it. Despite how well we embrace the online world, what has surfaced so strongly is our need to be with other people. Possibly we can live vicariously through some of the articles in this edition as they take us beyond our own locations.

In this edition we begin with Gen Blades eloquently crafted article 'Walking as a wandering ethic of (re)location: A public 'pedagogy of hope' that addresses pedagogies of hope and extends the reflection on 'walking methodology', a previous Journal theme but one that takes on new resonance in our current times. In this article Blades notes the social and environmental upheaval of both the bushfires and the pandemic. She asks the question of how the associated feelings of hopelessness and despair can be transformed to hope? What are the ethical and pragmatic considerations in such a transformation?

We then move to a different inward space with Melina Mallos' article, 'Exploring the identities of Greek migrant young adults through their new media use: Combining public pedagogy, participatory narrative inquiry, a/r/tography and heteroglossia'. This article is an analysis of how the role of media technology, specifically video conferencing, can be productively explored. How does this and other digital mediums shape identity and contribute to a sense of belonging amongst Greek migrant young people. Mallos alerts us to the instability of identity and the capacity for shifting perspectives through digital narrative mediation.

Debbie Qadri's 'Hosier and, Rutledge Lanes-where anyone can go and make art and other stories', entails the author's reconsideration of prior experiences of Melbourne's CBD Laneways. As Qadri notes these laneways attract substantial numbers of tourists and as a result are tolerated by the Government as graffiti sites. However, despite this sense of relative freedom this article demonstrates the layered gendered experience of graffiti artists in interviews with women pasting up work on International Women's Day. I would be remiss not to mention the textured use of words and illustrations in this article making Qadri's work both a pleasure to read and to look at.

In Amber Smith's 'Walking and collecting: How can our thinking on materials and process in contemporary collection-based art be realised through the act and purpose of walking?', we walk once more. This article problematises walking as an artistic modality, a step in a creative process. Through walking and collecting Smith alerts us to the nuanced confluence of an ephemeral moment of perception. For a moment the objects we collect say something of what we were thinking at that point in time. However, there is no lasting understanding of the initial intent of what we have collected. The formation of art in this way draws our attention to what we can avail ourselves with through walking in the public realm.

Greg Giannis continues this theme of walking in a beautifully written piece 'One step and I am Elsewhere' on his residency on the island of Lesvos, Greece, his ancestral home. Giannis has re-connected with place through walking and he maps these journeys through the use of a web-based, self-developed application that captures the walks through image, sound and text. In short, he produces an artwork. This piece reflects on the beginnings of this project in 2008 where he describes an encounter with Albanian Refugees and Giannis' 
subsequent return in 2019. In the intervening time both his parents had passed away. This article is a moving re-connection both to place, people and a changing landscape.

In the final article we return to art in public spaces through a visual essay titled 'Learning and Experiencing Intra-active Public Pedagogies in Melbourne's Laneways: Becoming Part of the Palimpsest' by Jennifer Sandlin and Jayson Cooper. Drawing on Biesta and Barad the authors outline a pedagogy of intra-action. In so doing the authors re-imagine street art as pedagogy through Biesta's concept of pedagogy in the interest of publicness. A key element of Biesta's understanding of publicness as activist is people coming together to enact change. However, to move this concept forward into the realm of new materialism, the authors are attentive to relationships of mutual constitutions of meaning beyond the instances of the artwork on the wall and the human encounter with such work to a consideration of what else might be realised.

Lastly, two books have been reviewed, Mike Cole's Trump, the Alt-right and Public Pedagogies of Hate and for Fascism - What is to be Done? and Theresa May, The Hostile Environment and the Public Pedagogies of Hate and Threat — the Case for a Future Without Borders.

I think you will find many ideas in this edition of the Journal to stimulate our thinking. At the time of writing this editorial we don't know how and when this will all end. But I hope through this Journal and the broader work of the Public Pedagogies Institute we can keep a sense of public connection albeit virtual.

Dr. Karen Charman 